\title{
PKM Pengrajin Pisau Di Kabupaten Trenggalek
}

\author{
Muhammad Malyadi ${ }^{1)}$, Fauzan Masykur²) \\ ${ }^{1)}$ Teknik Mesin, Universitas Muhammadiyah Ponorogo \\ ${ }^{2)}$ Teknik Informatika, Universitas Muhammadiyah Ponorogo \\ Jl. Budi Utomo No 10 Ponorogo \\ Email :muhmalyadi@gmail.com, fauzan.art@gmail.com
}

\begin{abstract}
Abstrak
Proses produksi pisau di Kabupaten Trenggalek selama ini masih menggunakan proses produksi secara konvensional namun masih tetap berkualitas. Proses produksi pisau melibatkan beberapa jenis pekerjaan yakni proses pekerjaan pembuatan pisau, proses pembuatan gagang pisau hingga proses finishing. Pada kegiatan pengabdian masyarakat kali ini ditekankan pada proses pembuatan gagang pisau dengan memanfaatkan sampah-sampah plastik. Mesin injeksi ini didesain sedemikian rupa sehingga mampu menghasilkan sebuah gagang pisau yang kuat dan tahan lama.Selain itu, gagang pisau yang terbuat dari sampah plastik bisa menggantikan peran kayu yang selama ini mendominasi material gagang pisau. Ada manfaat lain dari pembuatan gagang pisau dari plastik ini adalah mengurangi sampah plastik yang bertebaran di dilingkungan sekitar. Jenis plastik sebagai bahan baku utama gagang pisau harus dipilah terlebih dahulu supaya menghasilkan gagang pisau yang handal dan awet. Adapun jenis plastik yang bisa digunakan adalah plastik jenis HDPE (High density polyethylene).Plastik jenis HDPE ini merupakan jenis plastik paling aman di daur ulang dan paling sering di daur ulang.Mesin injeksi plastik ini didesain mampu meleburkan sampah plastik pada suhu $250^{\circ} \mathrm{c}$ dengan membutuhkan waktu 15 menit menjadikan plastik menjadi leleh dan siap dicetak sesuai keinginan menggunakan cetakan. Namun proses pencetakan akan lebih cepat apabila cetakan sudah dalam keadaan panas. Selama 1 jam mampu menghasilkan 20 gagang pisau.
\end{abstract}

Kata kunci: mesin injeksi plastik, High Dnsity Polyethylene, gagang pisau, pengrajin pisau.

\section{PENDAHULUAN}

Produksi pisau di wilayah Trenggalek ini terdiri dari berbagai jenis pisau atau senjata tajam, antara lain : pisau dapur, pisau pemotong daging, sabit, cangkul, parang dan lain-lain. Namun dari berbagai jenis produksi yang dihasilkan jenis pisau dapau dan sabit adalah jenis pisau yang sering diproduksi dikarenakan kebutuhan pasar masih kurang atau konsumen masih banyak yang membutuhkan. Sedangkan bahan baku utama pembuatan berbagai jenis pisau tersebut adalah plat besi atau juga dari stainless steel. Plat besi masih mendominasi bahan baku dikarenaan lebih murah dan mudah ditemui di pasar loak. Proses produksi berbagai jenis pisau disini ada yang diproduksi atas dasar kebutuhan pasar dan juga adanya pesanan dari pelanggan. Dari pembuatan pisau ini terdapat satu pekerjaan pendukung yakni pembuatan gagang pisau.Selama ini gagang pisau terbuat dari kayu yang dibentuk sedemikian rupa supaya nyaman saat digunakan atau saat di pegang. Namun penggunaan kayu sebagai bahan baku gagang pisau rentan terhadap tingkat ketahanan gagang pisau. Seperti kita ketahui kayu bisa mudah rapuh dan juga bahan baku kayu yang bagus mahal harganya dan akan berimbas pada harga pisau tersebut. Proses pembuatan pisau dikerjakan secara tradisional. Bahan baku plat besi baja maupun stainless steel dipotong dan ditempa sesuai bentuk yang diinginkan. Setelah terbentuk pisau yang diinginkan, pisau kemudian diasah untuk menambah ketajaman pisau. Dengan tangan-tangan yang telah terlatih, kualitas pisau ini dapat diandalkan

Bahan baku gagang pisau yang terbuat dari kayu tersebut diganti dari bahan baku plastik yang berserakan di lingkungan sekitar. Penggunaan bahan baku plastik lebih ramah lingkungan dan murah. Ide awal penggunaan plastik sebagai bahan baku gagang pisau ini dikarenakan sampah plastik yang berserakan di sekitar tempat tinggal. Dengan menggunakan mesin injeksi, sampah-sampah plastik yang semula hanya 
sampah belaka bisa digunakan sebagai bahan baku yang lebih bermanfaat dan bernilai jual di pasaran. Selain pemanfaatan sampah plastik, proses produksi gagang pisau berbahan dasar plastik merupakan sebuah proses daur ulang (re-cycle) dari bahan jadi yang sudah ada kemudian di proses sedemikian menjadi bentuk produk lainnya.

Jenis-jenis plastik yang paling sering diolah adalahpolyethylena (PE), polypropylene (PP), polistirena (PS),polyethylene terephthalate (PET) dan polyvinyl chloride(PVC). Jenis plastik yang dapat didaur ulang diberi kodeberupa nomor untuk memudahkan dalam mengidentifikasi.Nomor kode plastik akan tercantum pada produk-produkberbahan plastik seperti gambar berikut ini : [2]

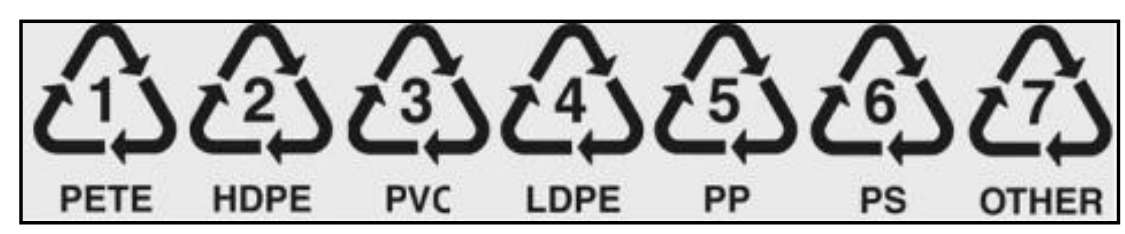

Gambar 1. Nomor Kode Plastik

Jenis plastik yang akan di daur ulang menjadi sebuah gagang pisau adalah jenis plastik jenis HDPE (High density polyethylene. Jenis HDPE ini merupakan jenis plastik yang mudah di daur ulang menjadi sebuah gagang pisau yang memiliki tingkat kekuatan dan kehandalan yang cukup bagus.Proses pembuatan kerajinan pisau ini di perlihatkan pada gambar 2 berikut.

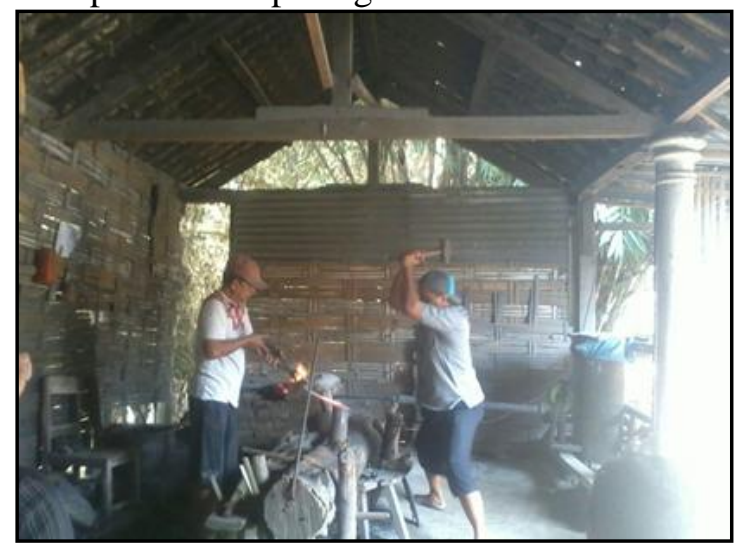

Gambar 2. Proses pembuatan kerajianan pisau

\section{METODE}

Proses kegiatan daur ulang sampah plastik menjadi sebuah gagang pisau ini melalui beberapa proses yakni :

a. Identifikasikebutuhan

Dari survei lapangan ditemukan bahwa pengrajin pisau saat ini menggunakan bahan kayu sebagai gagang pisau. Kelemahan dari bahan kayu adalah cepat lapuk, bahan sulit ditemukan sehingga ongkos produksi mahal, yang berimbas pada harga produk yang mahal, dan daya cengkeram kurang kuat. Oleh karena itu disarankan untuk memanfaatkan limbah plastik untuk dibuat gagang pisau dengan sebuah alat injeksi plastik.

b. Perancanganrangka

Rangka dirancang dengan material baja agar kuat menahan beban alat pada waktu beroperasi.

c. Perancangan tabunginjeksi

Tabung injeksi digunakan untuk menampung biji plastik kemudian dipanaskan sampai meleleh. Tabung ini dapat menampung sekitar 20 cc plastik cair.

d. Perancangan sistempemanas

Sistem pemanas menggunakan heater yang mampu mencapai temperatur $250^{\circ} \mathrm{C}$. 
e. Perancangan sistemkontrol

Sistem kontrol menggunakan arduino UNO. Berfungsi untuk mengatur dan menjaga temperatur pemanasan.

f. Desain dan rancangancetakan

peracangan dies dibuat untuk berbagai macam bentuk gagang pisau. Material yang digunakan adalah baja.

\section{HASIL DAN PEMBAHASAN}

\subsection{Kegiatan dan Pelaksanaan}

Langkah awal dalam pelaksanaan pengabdian kepada masyarakat ini adalah dengan pengumpulan data tentang apa saja yang dibutuhkan mitra sehingga pelaksanaannya bisa tepat sasaran dan sesuai kebutuhan mitra. Adapun pelaksaanaan kegiatan ini di biayai oleh kemristekdikti melalui hibah pengabdian kepada masyarakat pada tahun 2018.

\subsection{Waktu dan Tempat Pelaksanaan}

Waktu dan pelaksaan kegiatan pengabdian kepada masyarakat ini dilaksanakan dalam rentang waktu bulan juni 2018 hingga oktober 2018.Pelaksanaannya di awali dengan survey tentang kebutuhan mitra dalam pengelolaan kerajinan pisau atau senjata tajam lainnya.Sedangkan tempat pelaksanaan di laksanakan di Kabupaten Trenggalek tempat mitra berproduksi.Namun dalam hal desain dan perancangan mesin injeksi dilaksanakan di kampus Universitas Muhammadiyah Ponorogo tepatnya di Laboratorium Teknik Mesin.

\subsection{Mitra}

Sebagai mitra dalam pelaksanaan kegiatan pengabdian kepada masyarakat ini adalah sebuah UKM yang bergerak di bidang kerajinan pisau yang dipimpin oleh Bapak Paidi yang bertempat di Kabupaten Trenggalek Jawa Timur.UKM ini sudah lama memulai usaha kerajinan pisau namun masih menggunakan cara-cara tradisional dan belum menggunakan sentuhansentuhan teknologi tepat guna. Bapak Paidi ini dalam proses produksi pisau dibantu oleh 2 rekan kerjanya yakni Bapak Yanti dan Bapak Hari.

\subsection{Pembahasan dan Hasil}

Dari proses pengerjaan daur ulang sampah plastik menjadi gagang pisau ini dengan cara pembuatan mesin injeksi plastik yang di desain mempu meleburkan plastik hingga leleh kemudian di injeksikan ke sebuah cetakan gagang pisau dengan berbagai bentuk gagang pisau. Adapun spesifikasi mesin injeksi plastik tersebut sebagai berikut :

Tabel 1. Spesifikasi Mesin Injeksi

\begin{tabular}{|l|l|}
\hline Kapasitas & $: 20 \mathrm{cc}$ \\
\hline Waktu pengoperasian & $: 15$ menit/proses \\
\hline Dimensi & $: 23 \times 45 \times 63 \mathrm{~cm}$ \\
\hline Listrik & $: 300 \mathrm{~W} \mathrm{AC}$ \\
\hline Temperatur Pemanasan & $: 250^{\circ} \mathrm{C}$ \\
\hline Jenis Plastik & $:$ HDPE \\
\hline Cetakan & $:$ Dies berbagai bentuk \\
\hline
\end{tabular}

Sedangkan desain bentuk mesin injeksi yang digunakan untuk men-daur ulang sampah plastik menjadi gagang pisau sebagai berikut : 


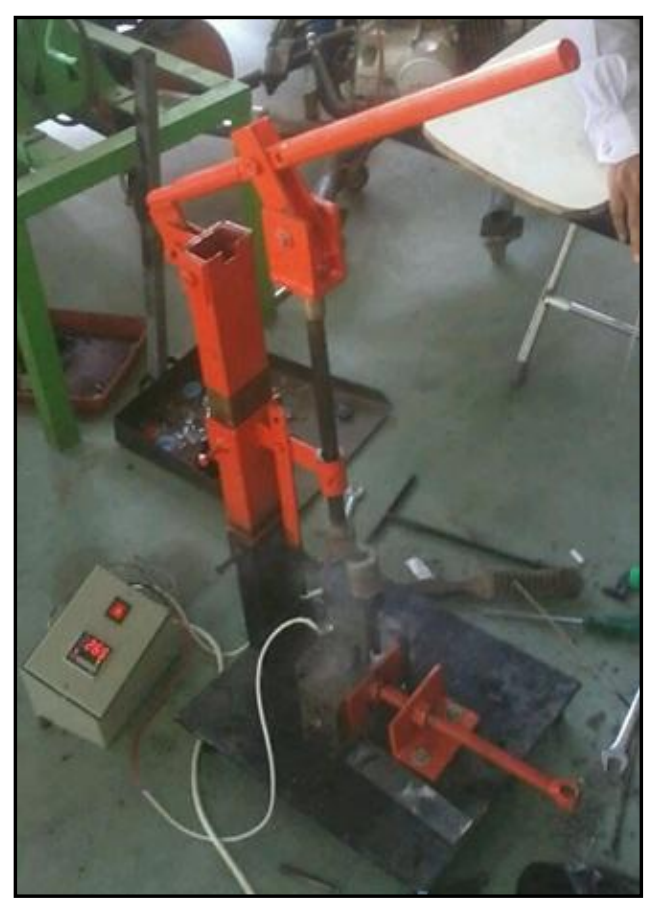

Gambar 3. Mesin Injeksi Plastik

Mesin injeksi plastik ini dirancang dengan berbagai macam cetakan gagang pisau sehingga gagang pisau yang dihasilkan akan lebih bervariasi. Penampingan dan pelatihan penggunaan mesin injeksi terus dilakukan supaya mitra tidak mengalami kebingungan saat penggunaan mesin injeksi. Pendampingan dan pelatihan di laksanakan mulai dari tahap awal hingga tahap finishing. Pada gambar 4 di bawah ini ditunjukkan saat pendampingan dan pelatihan di lokasi mitra.

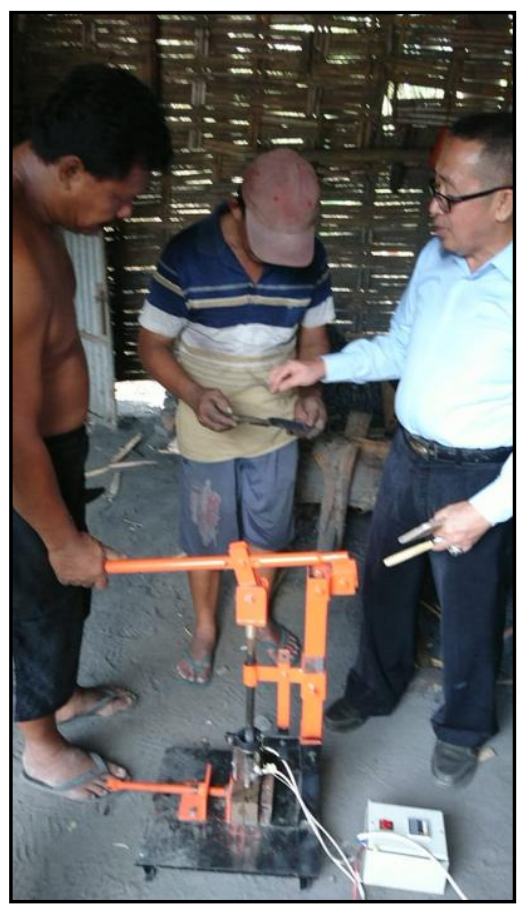

Gambar 4. Pendampingan dan Pelatihan

Setelah melalui proses pendampingan dan pelatihan kepada mitra pengabdian telah menghasilkan berbagai produk pisau dengan aneka ragam macam gagang pisau. Namun dalam hal produksi pisau disini belum maksimal dikarenakan untuk prosuksi pisau masih sebatas pesanan dari konsumen. Order dari konsumen sangat menentukan produksi jenis pisau tapi untuk jenis 
peralatan lain tetap berproduksi dikarenakan omzet penjualan tetap baik. Adapun hasil produksi yang telah dihasilkan oleh pengrajin pisau ini sdapat dilihat pada gambar 5 di bawah ini

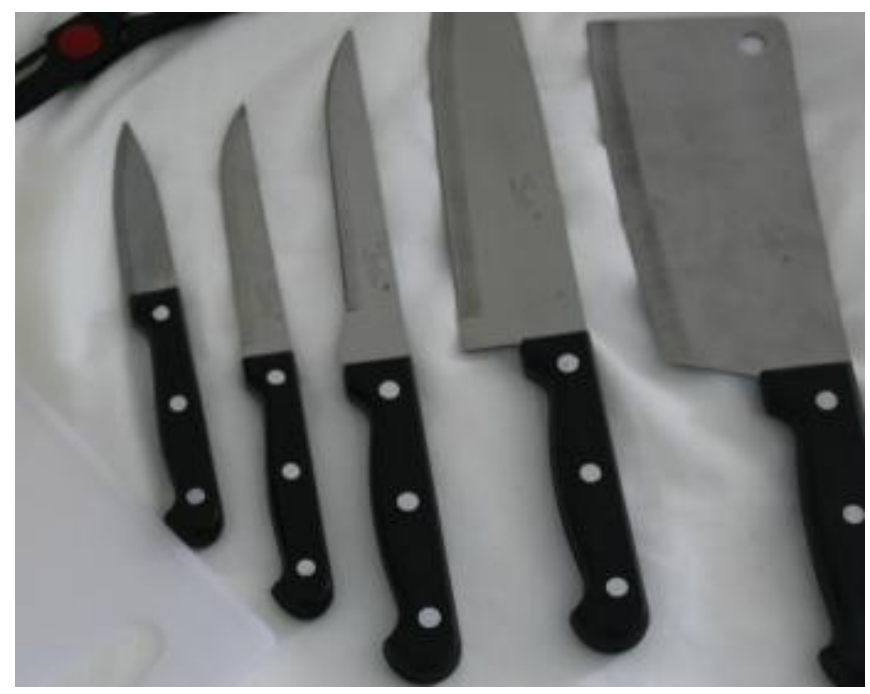

Gambar 5. Pisau Hasil Produksi Pengrajin

\section{KESIMPULAN}

Dari pelaksanaan program pengabdian kepada masyarakat melalui skema Program Kemitraan Masyarakat Kemristekdikti dapat ditarik beberapa kesimpulan, yakni :

1. Pelaksanaan program diperlukan adanya pendampingan yang berkesinambungan supaya mendapat hasil yang lebih baik

2. Perancangan dan pembuatan mesin injeksi sampah plastik merupakan salah satu cara daur ulang sampah menjadi barang yang lebih bermanfaat.

3. Penerapan teknologi tepat guna sebagai salah satu cara dalam peningkatan efisiensi waktu pekerjaan dan mendapatkan hasil yang lebih memuaskan.

\section{SARAN}

Adapun saran kami untuk pelaksanaan kegiatan pengabdian kepada masyarakat selanjutnya adalah menerapkan teknologi tepat guna (TTG) untuk mendukung kegiatan mitra dalam menghasilkan produk yang lebih berkualitas dan berdaya saing.

\section{UCAPAN TERIMA KASIH}

Penulis mengucapkan terima kasih kepada kemristekdikti yang telah memberi dukungan dana untuk kegiatan Pengabdian kepada masyarakat pada skema Program Kemitraan Masyarakat (PKM).

\section{DAFTAR PUSTAKA}

[1]. Hidayat dan Nugraha. 2017. Perancangan Alat Injeksi Plastik Untuk Gagang Pisau Pada UKM Pengrajin Pisau Di Desa Hadipolo Kudus. SNATIF 2017. Kudus

[2]. Surono dan Ismanto. 2016. Pengolahan Sampah Plastik Jenis PP, PET dan PE MenjadiBahan Bakar Minyak dan Karakteristiknya. Jurnal Mekanika dan Sistem Termal (JMST). Vol. 1(1)2016:32-37. Universitas Janabadra 